\title{
Vitamin D Deficiency Prevalence in Late Neonatal Hypocalcemia: A Multicenter Study
}

\author{
(D) Gülcan Seymen-Karabulut1, (D) Ayla Günlemez², (D) Ayşe Sevim Gökalp², (D Şükrü Hatun³, (D) Fatma Kaya Narter4*, \\ (D) Mehmet Mutlu5*, (D Şebnem Kader6*, (D) Demet Terek7*, (D) Deniz Hanta8*, (ID Emel Okulu9*, (D) Leyla Karadeniz10*, \\ (D) H. Gözde Kanmaz Kutman11*, (D) Ayşegül Zenciroğlu12*, (D) Özmert M.A. Özdemir13*, (D) Dilek Sarıcı14*, (D) Muhittin Çelik15*, \\ (D) Nihat Demir16*, (D) Özden Turan 17*, (D) Kıymet Çelik18*, (D) Fatih Kılıçbay2*, (D) Sinan Uslu19*, (D) Sara Erol20*, \\ (D) Sabahattin Ertuğrul21*, (D) ilkay Er22*, (D) Hasan Tolga Çelik23*, (D) Merih Çetinkaya24*, (D) Filiz Aktürk-Acar5*, (D) Yakup Aslan5*, \\ (D) Gaffari Tunç9*, (D) Ömer Güran10*, (D) Ayşe Engin Arısoy2* \\ 1 University of Health Sciences Turkey, Ümraniye Training and Research Hospital, Clinic of Pediatrics, Division of Pediatric Endocrinology, Istanbul, Turkey \\ ${ }^{2}$ Kocaeli University Faculty of Medicine, Department of Pediatrics, Division of Neonatology, Kocaeli, Turkey \\ ${ }^{3}$ Koç University Faculty of Medicine, Department of Pediatrics, Division of Pediatric Endocrinology, Istanbul, Turkey \\ ${ }^{4}$ Dr. Lütfi Kırdar Training and Research Hospital, Clinic of Pediatrics, Division of Neonatology, İstanbul, Turkey \\ ${ }^{5}$ Karadeniz Technical University Faculty of Medicine, Department of Pediatrics, Division of Neonatology, Trabzon, Turkey \\ 6 Trabzon Kanuni Training and Research Hospital, Clinic of Pediatrics, Division of Neonatology, Trabzon, Turkey \\ 7 Ege University Faculty of Medicine, Department of Pediatrics, Division of Neonatology, Izmir, Turkey \\ ${ }^{8}$ Adana Women and Children Hospital, Clinic of Pediatrics, Division of Neonatology, Adana, Turkey \\ ${ }^{9}$ Ankara University Faculty of Medicine, Department of Pediatrics, Division of Neonatology, Ankara, Turkey \\ 10 University of Health Sciences Turkey, Ümraniye Training and Research Hospital, Clinic of Pediatrics, Division of Neonatology, Istanbul, Turkey \\ 11Zekai Tahir Burak Maternity Training and Research Hospital, Clinic of Pediatrics, Division of Neonatology, Ankara, Turkey \\ 12 University of Health Sciences Turkey, Ankara Dr. Sami Ulus Maternity Women and Children Training and Research Hospital, Clinic of Pediatrics, Division \\ of Neonatology, Ankara, Turkey \\ 13Pamukkale University Faculty of Medicine, Department of Pediatrics, Division of Neonatology, Denizli, Turkey \\ ${ }^{14}$ Keçiören Training and Research Hospital, Clinic of Pediatrics, Division of Neonatology, Ankara, Turkey \\ ${ }^{15}$ Diyarbakır Children Hospital, Clinic of Pediatrics, Division of Neonatology, Diyarbakır, Turkey \\ ${ }^{16}$ Van Yüzüncü Yıl University Faculty of Medicine, Department of Pediatrics, Division of Neonatology, Van, Turkey \\ ${ }^{17}$ Başkent University Faculty of Medicine, Department of Pediatrics, Division of Neonatology, Ankara, Turkey \\ ${ }^{18}$ Dr. Behçet Uz Children Training and Research Hospital, Clinic of Pediatrics, Division of Neonatology, Izmir, Turkey \\ ${ }^{19}$ Şişli Hamidiye Etfal Training and Research Hospital, Clinic of Pediatrics, Division of Neonatology, İstanbul, Turkey \\ ${ }^{20}$ Etlik Zübeyde Hanım Maternity Training and Research Hospital, Clinic of Pediatrics, Division of Neonatology, Ankara, Turkey \\ ${ }^{21}$ Dicle University Faculty of Medicine, Department of Pediatrics, Division of Neonatology, Diyarbakır, Turkey \\ 22Derince Training and Research Hospital, Clinic of Pediatrics, Division of Neonatology, Kocaeli, Turkey \\ ${ }^{23}$ Hacettepe University Faculty of Medicine, Department of Pediatrics, Division of Neonatology, Ankara, Turkey \\ ${ }^{24}$ Kanuni Training and Research Hospital, Clinic of Pediatrics, Division of Neonatology, Istanbul, Turkey \\ *on behalf of Neonatal Study Group
}

What is already known on this topic?

Late neonatal hypocalcemia (LNH) occurs after the first 72 hours and the most common causes include excessive phosphate intake, hypomagnesemia, hypoparathyroidism, and vitamin D deficiency.

What this study adds?

Maternal vitamin D deficiency was found to be the most common cause of LNH in our study. Due to the immaturity of regulating factors of parathyroid hormone (PTH) and calcium, serum intact PTH levels may not reach expected levels and serum phosphorus levels may remain high in vitamin $\mathrm{D}$ deficient neonates, posing a diagnostic dilemma by mimicking primary hypoparathyroidism.

Address for Correspondence: Gülcan Seymen Karabulut MD, University of Health Sciences Turkey, Ümraniye Training and Research Hospital, Clinic of Pediatrics, Division of Pediatric Endocrinology, İstanbul, Turkey Phone: + 905053772525 E-mail: gulcansk@gmail.com ORCID: orcid.org/0000-0003-061 4-4083
Conflict of interest: None declared Received: 14.09 .2020 Accepted: 15.04.2021

${ }^{\circ}$ Copyright 2021 by Turkish Pediatric Endocrinology and Diabetes Society

The Journal of Clinical Research in Pediatric Endocrinology published by Galenos Publishing House. 


\section{Abstract}

Objective: Late neonatal hypocalcemia (LNH) is a common metabolic problem associated with hypoparathyroidism, high phosphate intake and vitamin D deficiency, often presenting with seizures. In this cross-sectional study, we aimed to evaluate the role of vitamin D deficiency in LNH in Turkey and to describe the characteristics of affected newborns.

Methods: Conducted with a cross-sectional design and with the participation of 61 neonatal centers from December 2015 to December 2016, the study included term neonates with LNH $(n=96)$ and their mothers $(n=93)$. Data were registered on the FAVOR Web Registry System. Serum samples of newborns and mothers were analyzed for calcium, phosphate, magnesium, albumin, alkaline phosphatase, intact parathyroid hormone (iPTH) and 25 hydroxyvitamin D [25(OH)D] levels.

Results: The median (range) onset time of hypocalcemia was 5.0 (4.0-8.0) days of age, with a male preponderance (60.4\%). The median (range) serum 25(OH)D levels of the neonates and their mothers were 6.3 (4.1-9.05) and 5.2 (4.7-8.8) ng/mL, respectively. The prevalence of vitamin D deficiency ( $<12 \mathrm{ng} / \mathrm{mL})$ was high in both the neonates $(86.5 \%)$ and mothers $(93 \%)$. Serum $25(\mathrm{OH}) \mathrm{D}$ levels of the infants and mothers showed a strong correlation $(p<0.001)$. While the majority $(93.7 \%)$ of the neonates had normal/high phosphorus levels, iPTH levels were low or inappropriately normal in $54.2 \%$ of the patients.

Conclusion: Vitamin D deficiency prevalence was found to be high in LNH. Efforts to provide vitamin D supplementation during pregnancy should be encouraged. Evaluation of vitamin D status should be included in the workup of LNH.

Keywords: Vitamin D deficiency, hypocalcemia, infant, newborn

\section{Introduction}

Neonatal hypocalcemia is defined as a total serum calcium (Ca) level of less than $7.5 \mathrm{mg} / \mathrm{dL}$ and ionized calcium $\left(\mathrm{Ca}^{2+}\right)$ level of less than $4.4 \mathrm{mg} / \mathrm{dL}$ in term newborns. Neonatal hypocalcemia may manifest as signs of neuromuscular hyperexcitability (irritability, jitteriness, tetany, laryngospasm, and seizures), apnea, cyanosis, feeding problems, and/or cardiac rhythm disturbances $(1,2)$. The causes of neonatal hypocalcemia are classified by the time of onset. Early neonatal hypocalcemia occurs within the first three days after birth, with an exaggeration of normal decline in serum Ca concentration in the first two postnatal days (2). Late neonatal hypocalcemia (LNH) occurs after the third day of birth, with the main causes being a high phosphate intake, hypoparathyroidism, parathyroid hormone (PTH) resistance, hypomagnesemia, and perinatal vitamin D deficiency. Neonatal vitamin D levels depend on maternal vitamin D status, breast-feeding, and sunlight exposure $(3,4)$. The risk factors for maternal vitamin D deficiency include habitation at high altitude, darker skin pigmentation, and excessive skin coverage with clothing. Most studies conducted in developing countries, including Turkey, have shown a high prevalence of hypovitaminosis D in newborns with a direct relationship with maternal vitamin D levels $(5,6,7,8,9,10,11)$. Maternal vitamin D deficiency results in a poor transplacental transmission of vitamin D during pregnancy and reduced storage in newborns, leading to reduced intestinal $\mathrm{Ca}$ absorption, reduced ionized $\mathrm{Ca}$ concentrations, and secondary hyperparathyroidism, which in turn decreases urinary $\mathrm{Ca}$ loss, increases bone $\mathrm{Ca}$ reabsorption, normalizes serum Ca levels, but also decreases renal phosphate reabsorption $(12,13)$. The reduced serum phosphate concentration is mainly responsible for the development of rickets, by impairing apoptosis of hypertrophic chondrocytes in the growth plate. In newborns and early infancy, a high metabolic demand for $\mathrm{Ca}$, PTH resistance, and/or inadequate $\mathrm{PTH}$ response may result in hypocalcemia before radiological evidence of rickets (14). There are reports, albeit few in number, reporting hypocalcemia as a manifestation of vitamin $\mathrm{D}$ deficiency $(15,16)$.

The aim of this study was to describe the clinical and biochemical characteristics of neonates with LNH, and to determine the relationship between LNH and maternal vitamin D deficiency in Turkey.

\section{Methods}

This cross-sectional, nationwide study was carried out between December 2015 and 2016 with the participation of 61 centers, and involved term neonates with LNH and their mothers. The study was endorsed by the Turkish Neonatology Society.

A case recording form (CRF), designed by two pediatric endocrinologists and a neonatologist (G.S.K., S.H., A.G.), was used to collect demographic data: maternal history including maternal clothing, lifestyle, and use of vitamin D supplements during pregnancy; anthropometric and clinical findings of the neonates; and laboratory findings of the newborns and their mothers. The CRF was uploaded to the FAVOR Web Registry System website. The study data were entered into the system over a 12-month period (December 11, 2015-2016) by the participating researchers. Data entered into the registry were also checked for consistency by a research assistant (G.S.K.). A total of 98 newborns with $\mathrm{LNH}$ and their mothers were registered in the database. 
The babies enrolled in our study were those who presented with hypocalcemia or who were hospitalized for other reasons and developed hypocalcemia during their followup. Hypocalcemia in asymptomatic babies was identified through routine biochemical tests during the hospital stay.

Inclusion criteria were term newborns born at 37-42 weeks of gestation and the presence of $\mathrm{LNH}$, defined as total serum Ca level of less than $7.5 \mathrm{mg} / \mathrm{dL}$ after the first 72 hours of birth. Registered data were reviewed in terms of the following exclusion criteria: a birthweight of less than 2,000 $g$ and the presence of maternal diabetes; neonatal asphyxia; sepsis; malabsorption; renal insufficiency; liver disease; or use of anticonvulsants. Neonates fed with breast milk and/ or formula were enrolled in the study.

Maternal and newborn venous blood samples were drawn at presentation to measure serum levels of total $\mathrm{Ca}$, phosphate $\left(\mathrm{PO}_{4}\right)$, magnesium (Mg), albumin, alkaline phosphatase (ALP), intact PTH (iPTH), and 25 hydroxyvitamin D [25(OH) D]. Serum Ca, P, ALP, and iPTH levels were measured on the same day; for $25(\mathrm{OH}) \mathrm{D}$, the blood supernatant samples after centrifugation were stored at $-80{ }^{\circ} \mathrm{C}$ until the time of assay in a single laboratory using an enzyme immunoassay method (IDS Immunodiagnostic Systems Ltd, Boldon, UK).

According to the Global Consensus Recommendations, maternal and neonatal 25(OH)D levels of less than $12 \mathrm{ng} /$ $\mathrm{mL}$ (30 nmol/L) were considered to be indicative of vitamin $\mathrm{D}$ deficiency (17). The inter- and intra-assay coefficients of variation were $6.7 \%$ and $8.7 \%$, respectively. The reference range for total $\mathrm{Ca}$ was $8.7-10.4 \mathrm{mg} / \mathrm{dL}$ in mothers (adult women). The normal range of inorganic phosphate was 5.2 to $8.4 \mathrm{mg} / \mathrm{dL}$ for infants $0-5$ months of age and 2.5 to 4.5 $\mathrm{mg} / \mathrm{dL}$ for adult women. The upper normal limits for ALP were $420 \mathrm{IU} / \mathrm{L}$ and $130 \mathrm{IU} / \mathrm{L}$ for infants and non-pregnant women, respectively (18). The normal range for iPTH was defined as 5-65 pg/mL.

Anterior fontanelle evaluation was performed using the following technique. The anteroposterior diameter (AB) was determined as the length and the transverse diameter (CD) as the width. The average of the longitudinal and transverse dimensions was recorded as the mean fontanelle size ([AB $+C D] / 2)$. Neonates with mean fontanelle size above $97^{\text {th }}$ percentile were determined as having large fontanelle (19).

Regular vitamin D intake during pregnancy was accepted as $1,200 \mathrm{IU} /$ day vitamin D starting from $12^{\text {th }}$ week of pregnancy, irrespective of vitamin D status, as stated in Turkish Ministry of Health Support Program (20).

The consistency and appropriateness of the diagnoses and enrolment were reviewed by two of the authors (G.S.K,
A.G.). After exclusion of two neonates and five mothers due to the lack of centrifuged serum samples for the $25(\mathrm{OH}) \mathrm{D}$ measurement, the final analyses included 96 newborns with newly-diagnosed late hypocalcemia and their 93 mothers.

Written informed consent was obtained from parents of the newborns, and the study protocol was approved by the Kocaeli University Ethics Committee (report number: KOU KAEK 2015/322).

\section{Statistical Analysis}

Data were processed using Statistical Package for the Social Sciences, version 20 (IBM Inc., Armonk, NY, USA). The data for normality of distrubition was assesed. Numerical variables were expressed as medians and are presented as interquartile range (IQR) and frequencies (percentages). The association between the maternal and neonatal $25(\mathrm{OH})$ D levels was evaluated by the Spearman's correlation coefficient. A p value of less than 0.05 was considered to be significant.

\section{Results}

Among the 96 neonates, which included 38 (39.6\%) girls and $58(60.4 \%)$ boys, with newly diagnosed late hypocalcemia, the median (IQR) age of onset was 5.0 (4.08.0) days (Table 1 ). Thirty-three (34.4\%) neonates presented with the symptoms of hypocalcemia, with convulsion being the most common symptom $(n=18)$. There was a seasonal pattern of presentation, with increased incidence in winter and spring months $(65.6 \%)$. The majority of mothers $(n=74,77.1 \%)$ used covered clothing and spent most of their time indoors. Only $20.4 \%$ of the mothers received regular vitamin D supplements during pregnancy.

Table 2 shows the laboratory findings of neonates with $\mathrm{LNH}$. The median (IQR) serum Ca level was 6.9 (6.4-7.2) $\mathrm{mg} / \mathrm{dL}$, serum phosphorus $7.2(6.1-8.5) \mathrm{mg} / \mathrm{dL}$, serum ALP 197 (142.5-279.2) IU/L, and serum iPTH 69.1 (37.4-106) pcg/ $\mathrm{mL}$. The median (IQR) serum vitamin D level was 6.3 (4.19.05) $\mathrm{ng} / \mathrm{mL}$, with 83 (86.5\%) neonates having vitamin $\mathrm{D}$ deficiency, defined as a serum 25(OH)D level $<12 \mathrm{ng} / \mathrm{mL}$. Serum phosphorus levels were normal/high in all but six neonates, and iPTH levels were high in 44 neonates $(45.8 \%)$.

The maternal median (IQR) serum vitamin D level was 5.2 (4.7-8.8) $\mathrm{ng} / \mathrm{mL}$, and $93 \%$ of the mothers were vitamin D deficient (Table 3).

All but three mothers with vitamin D deficiency had neonates who also had vitamin D deficiency. A strong positive correlation was found between maternal and neonate serum $25(\mathrm{OH}) \mathrm{D}$ levels $(\mathrm{r}=0.513, \mathrm{p}<0.001)$ (Figure 1). 


\begin{tabular}{|c|c|}
\hline Characteristics $(n=96)$ & Value* \\
\hline Age at onset of hypocalcemia, (days) & $5(4-8)$ \\
\hline $\begin{array}{l}\text { Sex } \\
\text { Male } \\
\text { Female }\end{array}$ & $\begin{array}{l}58(60.4) \\
38(39.6)\end{array}$ \\
\hline $\begin{array}{l}\text { Season of birth time } \\
\text { Winter (December-February) } \\
\text { Spring (March-May) } \\
\text { Summer (June-August) } \\
\text { Autumn (September- November) }\end{array}$ & $\begin{array}{l}27(28.1) \\
36(37.5) \\
14(14.6) \\
19(19.8)\end{array}$ \\
\hline $\begin{array}{l}\text { Living area } \\
\text { Urban } \\
\text { Rural }\end{array}$ & $\begin{array}{l}49(51) \\
47(49)\end{array}$ \\
\hline $\begin{array}{l}\text { Maternal clothing } \\
\text { Covered } \\
\text { Not covered }\end{array}$ & $\begin{array}{l}74(77.1) \\
22(22.9)\end{array}$ \\
\hline $\begin{array}{l}\text { Maternal vitamin D supplementation during } \\
\text { pregnancy } \\
\text { Regular } \\
\text { Irregular } \\
\text { None }\end{array}$ & $\begin{array}{l}19(20.4) \\
4(4.3) \\
70(75.3)\end{array}$ \\
\hline $\begin{array}{l}\text { Symptom }(+) \\
\text { Convulsion } \\
\text { Poor sucking reflex } \\
\text { Exaggerated startle } \\
\text { Lethargy } \\
\text { Vomiting } \\
\text { Cyanosis } \\
\text { Apnea }\end{array}$ & $\begin{array}{l}33(34.4) \\
18(18.8) \\
17(17.7) \\
11(11.5) \\
7(7.3) \\
3(3.1) \\
2(2.1) \\
1(1)\end{array}$ \\
\hline Large anterior fontanelle & $6(6.3)$ \\
\hline Gestational age (weeks) & $38(37-39)$ \\
\hline Birth weight (g) & $3305(2976-3640)$ \\
\hline $\begin{array}{l}\text { Apgar score } \\
1 \text {-minute } \\
5 \text {-minute }\end{array}$ & $\begin{array}{l}8(7-8) \\
9(9-10)\end{array}$ \\
\hline
\end{tabular}

*Values are presented as number (\%), median (interquartile range), or number only.

\section{Discussion}

This is the first cross-sectional, multi-center study of term neonates with late hypocalcemia to investigate the relationship between maternal vitamin D status and LNH in Turkey. Maternal and neonatal vitamin D deficiency was found to be related with neonatal late hypocalcemia. Although infants can be protected from severe hypocalcemia thanks to a nationwide program of free supplementation of 400 U/day vitamin D for infants, the problem of LNH will continue unless pregnant women are provided with and consistently use vitamin D supplementation (21).

The prevalence of inadequate vitamin D status is high among pregnant and lactating women around the world $(22,23,24)$. Women who wear covered clothing, live at high altitudes, and do not have an adequate exposure to sunlight are especially at risk for vitamin D deficiency (14).
Table 2. Biochemical parameters of 96 neonates with late neonatal hypocalcemia

\begin{tabular}{|c|c|c|c|}
\hline Variable & \multicolumn{2}{|l|}{ Median (IQR) } & $\mathrm{n}(\%)$ \\
\hline Calcium (mg/dL) & \multicolumn{3}{|l|}{$6.9(0.9)$} \\
\hline $\begin{array}{l}\text { Phoshorus (mg/dL) } \\
\text { (normal: } 5.2-8.4 \text { ) }\end{array}$ & $7.2(2.4)$ & $\begin{array}{l}\text { Low } \\
\text { Normal } \\
\text { High }\end{array}$ & $\begin{array}{l}6(6.3) \\
63(65.6) \\
27(28.1)\end{array}$ \\
\hline $\begin{array}{l}\text { ALP (IU/L) (normal: } \\
145-420)\end{array}$ & $197(136.7)$ & $\begin{array}{l}\text { Normal } \\
\text { High }\end{array}$ & $\begin{array}{l}87(90.6) \\
9(9.4)\end{array}$ \\
\hline $\begin{array}{l}\text { iPTH (pg/mL) (normal: } \\
5-65)\end{array}$ & 69.1 (68.6) & $\begin{array}{l}\text { Low } \\
\text { Normal } \\
\text { High }\end{array}$ & $\begin{array}{l}2(2.1) \\
50(52.1) \\
44(45.8)\end{array}$ \\
\hline $\begin{array}{l}25(\mathrm{OH}) \mathrm{D}(\mathrm{ng} / \mathrm{mL}) \\
(\text { deficiency }<12 \\
\text { insufficiency } 12-20 \\
\text { sufficiency }>20)\end{array}$ & $6.3(4.9)$ & $\begin{array}{l}\text { Deficiency } \\
\text { Insufficiency } \\
\text { Sufficiency }\end{array}$ & $\begin{array}{l}83(86.5) \\
5(5.2) \\
8(8.3)\end{array}$ \\
\hline $\begin{array}{l}\text { ALP: alkaline phosphatase, } \\
\text { hydroxyvitamin D, IQR: in }\end{array}$ & $\begin{array}{l}\text { TH: intact parath } \\
\text { quartile range, } n \text { : }\end{array}$ & $\begin{array}{l}\text { oid hormone, } 25 \\
\text { umber }\end{array}$ & D: 25 \\
\hline
\end{tabular}

Table 3. Biochemical parameters in mothers of term neonates with late neonatal hypocalcemia

\begin{tabular}{|c|c|c|c|}
\hline Variable & $\begin{array}{l}\text { Median } \\
\text { (IQR) }\end{array}$ & & $\mathrm{n}(\%)$ \\
\hline Calcium (mg/dL) & 8.9 (0.9) & & \\
\hline $\begin{array}{l}\text { Phoshorus (mg/dL) } \\
\text { (normal: } 2.5-4.5 \text { ) }\end{array}$ & $3.9(0.87)$ & $\begin{array}{l}\text { Normal } \\
\text { High }\end{array}$ & $\begin{array}{l}71(88.8) \\
9(11.3)\end{array}$ \\
\hline ALP (IU/L) (normal: < 150) & $126(60.1)$ & $\begin{array}{l}\text { Normal } \\
\text { High }\end{array}$ & $\begin{array}{l}57(70.4) \\
24(29.6)\end{array}$ \\
\hline $\begin{array}{l}\text { iPTH (pg/mL) (normal: } \\
10-65)\end{array}$ & $65.5(56.9)$ & $\begin{array}{l}\text { Low } \\
\text { Normal } \\
\text { High }\end{array}$ & $\begin{array}{l}1(1.1) \\
43(49.4) \\
43(49.4)\end{array}$ \\
\hline $\begin{array}{l}25(\mathrm{OH}) \mathrm{D}(\mathrm{ng} / \mathrm{mL}) \\
(\text { deficiency }<12 \\
\text { insufficiency } 12-20 \\
\text { sufficiency }>20)\end{array}$ & $5.2(4.1)$ & $\begin{array}{l}\text { Deficiency } \\
\text { Insufficiency } \\
\text { Sufficiency }\end{array}$ & $\begin{array}{l}80(93) \\
4(4.7) \\
2(2.3)\end{array}$ \\
\hline
\end{tabular}

ALP: alkaline phosphatase, iPTH: intact parathyroid hormone, 25(OH)D: 25 hydroxyvitamin D, IQR: interquartile range, $\mathrm{n}$ : number

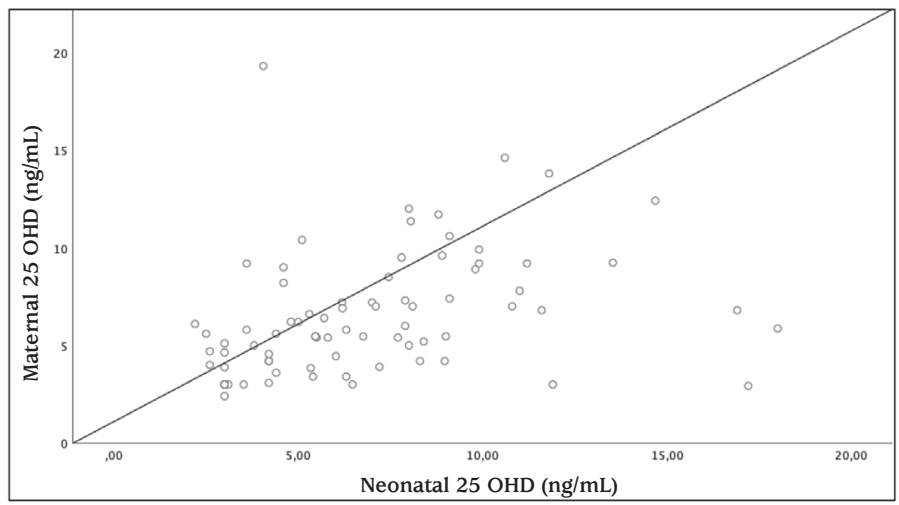

Figure 1. Correlation between maternal and neonatal serum 25 hydroxyvitamin D levels

In a study from Turkey, in lactating women and their babies a serum 25(OH)D level below $11 \mathrm{ng} / \mathrm{mL}$ was accepted as severe vitamin D deficiency, 11-25 ng/mL as moderate 
deficiency, and a value $>25 \mathrm{ng} / \mathrm{mL}$ as normal. Severe vitamin D deficiency was found in $27 \%$ of the mothers, and moderate deficiency in $54.3 \%$. Severe vitamin D deficiency was detected in $64.3 \%$ of the neonates, and moderate deficiency in $32.9 \%(24)$.

An Indian study by Mehrotra et al (5) in 2010 found that $90 \%$ of neonates with hypocalcemic convulsions and $89 \%$ of their mothers had vitamin D deficiency. Furthermore, a significant correlation was found between the serum $25(\mathrm{OH})$ $\mathrm{D}$ levels of the mothers and infants.

Hatun et al (15) examined the medical records of infants with vitamin D deficiency and/or nutritional rickets in Turkey and found that $79 \%$ of the infants whose mothers were also vitamin D deficient had presented with hypocalcemic seizures. In the present study, vitamin D deficiency was diagnosed in $86.5 \%$ of the neonates with late hypocalcemia and in $93 \%$ of their mothers and, consistent with many previous reports, there was a significant correlation between maternal and newborn 25(OH)D levels $(5,10)$.

As a known risk factor for vitamin D deficiency, covered clothing was seen in $77.1 \%$ of the mothers. Another study conducted in Turkey reported similar results (15). In a study carried out in Iran, where the vast majority of the population are Muslim and where women are required to veil themselves, among 100 neonates diagnosed with hypocalcemia, the prevalence of maternal vitamin D deficiency was $74 \%$ (9).

According to the Global Consensus Recommendations, the basic approach to prevent $\mathrm{LNH}$ is to supplement women with vitamin D of at least $600 \mathrm{U} /$ day particularly over the last three months of pregnancy. However, data from an earlier national study showed that $25(\mathrm{OH}) \mathrm{D}$ levels can be normalized only by the administration of $2000 \mathrm{U}$ of vitamin D per day during pregnancy (25).

In the current study, the majority of late hypocalcemic babies were born in the winter and spring months, which is consistent with a previous study from Korea that included 17 term newborns with LNH (26). This may be explained by limited sunlight exposure for mothers whose late pregnancy periods take place during the winter and spring months, leading to low maternal and neonatal vitamin D levels. We observed a male preponderance, which was previously reported by an American study of 78 full-term neonates with transient hypocalcemia, as well as by a study from the United Kingdom involving hypocalcemic neonates and children due to vitamin D deficiency $(27,28)$.

In our study, despite the high prevalence of vitamin $\mathrm{D}$ deficiency $(86.5 \%)$, large anterior fontanelle was observed in a small percentage of neonates $(6.3 \%)$. Since reduced serum phosphate concentration is mainly responsible for the skeletal findings of rickets, we can speculate that, regardless of the amount, continuous transplacental transfer of $\mathrm{Ca}$ and phosphorus to the fetus might have limited the clinical and biochemical manifestations of vitamin D deficiency in these neonates. Elevated PTH level is an important cause of decreased phosphorus reabsorption. However, in neonates and young infants, PTH resistance and/or inadequate PTH response may result in hypocalcemia before skeletal findings occur.

Vitamin D deficiency is associated with biochemical disruption to $\mathrm{Ca}$ homeostasis, resulting in a typical constellation of hypocalcaemia, hypophosphatemia, and elevated levels of alkaline phosphatase and PTH. Other studies have documented that vitamin D deficiency triggers PTH release in adults, children, and older infants. However, in newborns and young infants, this feedback loop appears not to occur, and hypovitaminosis D coexisted with blunted PTH response and/or PTH resistance $(29,30,31,32,33)$. In our study, baseline iPTH concentrations were increased in only $45.8 \%$ of neonates, and serum phosphorus levels were normal/high in all but five patients. Do et al (26) reported that, in 17 neonates with late-onset hypocalcemia secondary to vitamin D deficiency, iPTH levels were not remarkably elevated except in one case. Similar results in neonates were described by Maghbooli et al (34), who reported elevated serum iPTH levels in only $10 \%$ of vitamin $\mathrm{D}$ deficient neonates at birth. Late maturation of the parathyroid axis is thought to be a main cause of transient neonatal hypocalcemia, as suggested by the low or inappropriately normal PTH levels and high phosphorus levels in these infants. We also observed biochemically normal/high phosphorus levels in hypocalcemic neonates, although hyperparathyroidism is present, reflecting a possible PTH resistance. In the literature, some studies report PTH resistance in bone, secondary to vitamin D deficiency (15).

One of the basic points that we would like to emphasize is that a secondary increase in PTH level as a response to hypocalcemia (progress from stage 1 to stage 2) may not take place in vitamin D deficiency in early infancy. Thus, a decreased Ca level and normal or elevated serum phosphorus level in the presence of low and/or inappropriately normal iPTH level may be detected, mimicking hypoparathyroidism. This puzzles clinicians, and pseudohypoparathyroidism is considered for cases where PTH level is high. We would also like to stress that, in some vitamin D deficient cases, serum phosphorus levels may be normal or high, despite an increase in PTH level, due to secondary PTH resistance. Thus vitamin 
D deficiency should be kept in mind in the differential diagnosis of pseudohypoparathyroidism. Elevated serum PTH concentration in the face of hypocalcemia and normal/ high serum phosphate indicates an element of end organ resistance to PTH, mimicking pseudoparahypothyroidism. It was postulated in experimental rats that vitamin D depletion made them unresponsive to PTH. The vitamin D-depleted hypocalcemic rats failed to show elevation of serum $\mathrm{Ca}$ or a phosphaturic effect to injected PTH extracts, which could be corrected by addition of a small dose of vitamin $\mathrm{D}$. The end organ resistance observed in vitaminD deficiency could result from down regulation of PTH/PTHrP receptor (35). Rao et al (36) observed an impaired phosphaturic response but normal urinary cAMP excretion to PTH in vitamin D deficient infants, similar to the picture in pseudohypoparathyroidism. The response to PTH was restored to normal following vitamin D and Ca supplementation, suggesting that in the presence of vitamin D deficiency and/or hypocalcemia, the renal tubules are resistant to the action of PTH.

The aim of our study was to determine the prevalence of vitamin $\mathrm{D}$ deficiency in babies with $\mathrm{LNH}$, to draw attention to the importance of checking perinatal vitamin D levels when investigating the cause of LNH and to highlight that vitamin D deficiency may have biochemical findings leading to clinical confusion with other etiologies. Although the majority of the babies and their mothers included in our study was vitamin $\mathrm{D}$ deficient, we tried to be cautious not to indicate vitamin $\mathrm{D}$ deficiency as the sole reason for hypocalcemia in these babies. We wanted to emphasize that the prevalence of vitamin $\mathrm{D}$ deficiency is high in babies with hypocalcemia and it should be kept in mind as one of the leading possible causes. Cases of pseudohypoparathyroidism due to $\mathrm{G}$ protein receptor defects are known to present with symptoms after the newborn and infancy period (37). The cases that may be confused with vitamin D deficiency in the neonatal period are mainly of transient pseudohypoparathyroidism due to PTH receptor immaturity. In these cases, serum 25-OHD levels are not expected to be low. In addition, delay in both PTH release and the maturation in PTH receptors may be associated with neonatal vitamin D deficiency, which leads to biochemical findings, such as hyperphosphatemia and symptomatic hypocalcemia (15).

\section{Study Limitations}

A potential limitation of the study was the small number of the patients despite the participation of many centres. It is, however, difficult to recruit a large number of neonates with hypocalcemia in intensive care units due to the exclusion criteria including the presence of maternal diabetes, neonatal asphyxia, malabsorption, renal insufficiency, liver disease, or use of anticonvulsants and the concerns of parents about giving approval for taking blood samples from their babies. In addition, ELISA which was used in this study to measure vitamin D levels is not the gold standard test because of interference with vitamin $\mathrm{D}$ metabolites.

\section{Conclusion}

This study provides further evidence highlighting the need to maintain adequate vitamin D status in pregnancy. LNH has a close association with perinatal vitamin D deficiency. Thus the first step of a diagnostic work-up for LNH should be to measure serum 25(OH)D levels.

\section{Ethics}

Ethics Committee Approval: The study were approved by the Kocaeli University Ethics Committee (report number: KOU KAEK 2015/322).

Informed Consent: Written informed consent was obtained from parents of the newborns.

Peer-review: Externally and internally peer-reviewed.

\section{Authorship Contributions}

Concept: Gülcan Seymen-Karabulut, Ayla Günlemez, Ayşe Sevim Gökalp, Şükrü Hatun, Design: Gülcan SeymenKarabulut, Ayla Günlemez, Ayşe Sevim Gökalp, Şükrü Hatun, Data Collection or Processing: Fatma Kaya Narter, Mehmet Mutlu, Şebnem Kader, Demet Terek, Deniz Hanta, Emel Okulu, Leyla Karadeniz, H. Gözde Kanmaz Kutman, Ayșegül Zenciroğlu, Özmert M. A. Özdemir, Dilek Sarıcı, Muhittin Çelik, Nihat Demir, Özden Turan, Kıymet Çelik, Fatih Kılıçbay, Sinan Uslu, Sara Erol, Sabahattin Ertuğrul, İlkay Er, Hasan Tolga Çelik, Merih Çetinkaya, Filiz Aktürk-Acar, Yakup Aslan, Gaffari Tunç, Ömer Güran, Ayşe Engin Arısoy, Analysis or Interpretation: Gülcan Seymen-Karabulut, Ayla Günlemez, Literature Search: Gülcan Seymen-Karabulut, Ayla Günlemez, Şükrü Hatun, Writing: Gülcan SeymenKarabulut, Ayla Günlemez, Şükrü Hatun.

Financial Disclosure: This study was supported by Kocaeli University Scientific Research Fund.

\section{References}

1. Root AW, Diamond FB. Disorders of mineral homeostasis in children and adolescents. In: Sperling MA (ed). Pediatric Endocrinology. 4th ed. Philadelphia. Elsevier Saunders 2014;734-845.

2. Carpenter TO. Ma NS. Disorders of mineral metabolism in childhood. In: Bilezikian JP (ed). Primer on the Metabolic Bone Diseases and Disorders of Mineral Metabolism. 9th ed. Washington, American Society of Bone and Mineral Metabolism, 2008;705-712. 
3. Thomas SD, Fudge AN, Whiting M, Coates PS. The correlation between third-trimester maternal and newborn-serum 25-hydroxy-vitamin D in a selected South Australian group of newborn samples. BMJ Open 2011;1:e000236.

4. Specker BL, Valanis B, Hertzberg V, Edwards N, Tsang RC. Sunshine exposure and serum 25-hydroxyvitamin $\mathrm{D}$ concentrations in exclusively breast-fed infants. J Pediatr 1985;3:372-376.

5. Mehrotra P, Marwaha RK, Aneja S, Seth A, Singla BM, Ashraf G, Sharma B, Sastry A, Tandon N. Hypovitaminosis D and hypocalcemic seizure in infancy. Indian Pediatr 2010;47:581-586.

6. Pehlivan I, Hatun S, Aydoğan M, Babaoğlu K, Gökalp AS. Maternal vitamin D deficiency and vitamin D supplementation in healthy infants. Turk J Pediatr 2003;45:315-320.

7. Atiq M, Suria A, Nizami SQ, Ahmed I. Maternal vitamin-D deficiency in Pakistan. Acta Obstet Gynecol Scand 1998;77:970-973.

8. Dijkstra SH, van Beek A, Janssen JW, de Vleeschouwer LHM, Huysman WA, van den Akker ELT. High prevalence of vitamin D deficiency in newborn infants of high-risk mothers. Arch Dis Child 2007;92:750753.

9. Khalesi N, Bahaeddini SM, Shariat M. Prevalence of maternal vitamin D deficiency in neonates with delayed hypocalcaemia. Acta Med Iran 2012;50:740-745

10. Pehlivan I, Hatun S, Aydogan M, Babaoğlu K, Türker G, Gökalp AS. Maternal serum vitamin D levels in the third trimester of pregnancy. Turk J Med Sci 2002;32:237-241.

11. Andıran N, Yordam N, Ozon A. Risk factors for vitamin D deficiency in breast-fed newborns and their mothers. Nutrition 2002;18:47-50.

12. Ladhani S, Srinivasan L, Buchanan C, Allgrove J. Presentation of vitamin D deficiency. Arch Dis Child 2004;89:781-784.

13. Misra M, Pacaud D, Petryk A, Collett-Solberg PF, Kappy M; Drug and Therapeutics Committee of the Lawson Wilkins Pediatric Endocrine Society. Vitamin D deficiency in children and its management: review of current knowledge and recommendations. Pediatrics 2008;12:398-417.

14. Pettifor JM, Prentice A. The role of vitamin D in paediatric bone health. Best Pract Res Clin Endocrinol Metab 2011;25:573-584.

15. Hatun S, Ozkan B, Orbak Z, Doneray H, Cizmecioglu F, Toprak D, Calikoglu AS. Vitamin D deficiency in early infancy. J Nutr 2005; 135:279-282.

16. Ahmed I, Atiq M, Iqbal J, Khurshid M, Whittaker P. Vitamin D deficiency rickets in breast-fed infants presenting with hypocalcaemic seizures. Acta Paediatr 1995;84:941-942.

17. Munns CF, Shaw N, Kiely M, Specker BL, Thacher TD, Ozono K, Michigami T, Tiosano D, Mughal MZ, Mäkitie O, Ramos-Abad L, Ward L, DiMeglio LA, Atapattu N, Cassinelli H, Braegger C, Pettifor JM, Seth A, Idris HW, Bhatia V, Fu J, Goldberg G, Sävendahl L, Khadgawat R, Pludowski P, Maddock J, Hyppönen E, Oduwole A, Frew E, Aguiar M, Tulchinsky T, Butler G, Högler W. Global consensus recommendations on prevention and management of nutritional rickets. J Clin Endocrinol Metab 2016;101:394-415. Epub 2016 Jan 8

18. Pesce MA. Laboratory medicine. Nelson Textbook of Pediatrics. 18th ed. Philadelphia, Saunders, 2007;2944.

19. Boran P, Oğuz F, Furman A, Sakarya S. Evaluation of fontanel size variation and closure time in children followed up from birth to 24 months. J Neurosurg Pediatr 2018;22:323-329. Epub 2018 Jun 1

20. Turkish Ministry of Health. The guide of vitamin D supplementation of pregnant women; 2011. Available from: https://www.saglik.gov.tr/ TR, 11161/gebelere-d-vitamini-destek-programi-rehberi.html

21. Hatun S, Bereket A, Ozkan B, Coşkun T, Köse R, Calykoğlu AS. Free vitamin D supplementation for every infant in Turkey. Arch Dis Child 2007;92:373-374.
22. Institute of Medicine Food and Nutrition Board. In: Ross AC, Taylor CL, Yaktine Al, Del Valle HB (eds). Dietary Reference Intakes for Calcium and Vitamin D. Washington DC, The National Academies Press, 2011.

23. Vitamin D and Health. Scientific Advisory Committee on Nutrition (SACN). 2016. Available from: https://www.gov.uk/government/groups/ scientific-advisory-committee-on-nutrition

24. Ergür AT, Berberoğlu M, Atasay B, Şılar Z, Bilir P, Arsan S, Söylemez F, Öcal G. Vitamin D deficiency in Turkish mothers and their neonates and in women of reproductive age. J Clin Res Pediatr Endocrinol 2009;1:266-269. Epub 2009 Nov 3

25. Yesiltepe Mutlu G, Ozsu E, Kalaca S, Yuksel A, Pehlevan Y, Cizmecioglu F, Hatun S. Evaluation of vitamin D supplementation doses during pregnancy in a population at high risk for deficiency. Horm Res Paediatr 2014;81:402-408. Epub 2014 Apr 3

26. Do HJ, Park JS, Seo JH, Lee ES, Park CH, Woo HO, Youn HS. Neonatal late-onset hypocalcemia: is there any relationship with maternal hypovitaminosis D? Pediatr Gastroenterol Hepatol Nutr 2014;17:47-51. Epub 2014 Mar 31

27. Thomas TC, Smith JM, White PC, Adhikari S. Transient neonatal hypocalcemia: presentation and outcomes. Pediatrics 2012;129:e1461-e1467.

28. Basatemur E, Sutcliffe A. Incidence of hypocalcemic seizures due to vitamin D deficiency in children in the United Kingdom and Ireland. J Clin Endocrinol Metab 2015;100:E91-E95.

29. Portale A. Blood calcium, phosphorus and magnesium. In: Favus M (ed). Primer on the Metabolic Bone Diseases and Disorders of Mineral Metabolism. 4th ed. Philadelphia, Lippincott Williams \& Wilkins 1999:115-118.

30. Teaema FH, Al Ansari K. Nineteen cases of symptomatic neonatal hypocalcemia secondary to vitamin D deficiency: a 2-year study. J Trop Pediatr 2010;56:108-110. Epub 2009 Jul 21

31. Tseng UF, Shu SG, Chen $\mathrm{CH}$, Chi CS. Transient neonatal hypoparathyroidism: report of four cases. Acta Paediatr Taiwan 2001;42:359-362.

32. Lee CT, Tsai WY, Tung YC, Tsau YK. Transient pseudohypoparathyroidism as a cause of late-onset hypocalcemia in neonates and infants. J Formos Med Assoc 2008;107:806-810.

33. Hatun Ş, Ozkan B, Bereket A. Vitamin D deficiency and prevention: Turkish experience. Acta Paediatr 2011;100:1195-1199. Epub 2011 Jul 4

34. Maghbooli Z, Hossein-Nezhad A, Shafaei AR, Karimi F, Madani FS, Larijani B. Vitamin D status in mothers and their newborns in Iran. BMC Pregnancy Childbirth 2007;7:1.

35. Srivastava T, Alon US. Stage I vitamin D-deficiency rickets mimicking pseudohypoparathyroidism type II. Clin Pediatr (Phila) 2002;41:263268.

36. Rao DS, Parfitt AM, Kleerekoper M, Pumo BS, Frame B. Dissociation between the effects of endogenous parathyroid hormone on adenosine 3',5'-monophosphate generation and phosphate reabsorption in hypocalcemia due to vitamin D depletion: an acquired disorder resembling pseudohypoparathyroidism type II. J Clin Endocrinol Metab 1985;61:285-290.

37. Mantovani G, Bastepe M, Monk D, de Sanctis L, Thiele S, Usardi A, Ahmed SF, Bufo R, Choplin T, De Filippo G, Devernois G, Eggermann T, Elli FM, Freson K, García Ramirez A, Germain-Lee EL, Groussin L, Hamdy N, Hanna P, Hiort O, Jüppner H, Kamenický P, Knight N, Kottler ML, Le Norcy E, Lecumberri B, Levine MA, Mäkitie O, Martin R, MartosMoreno GÁ, Minagawa M, Murray P, Pereda A, Pignolo R, Rejnmark L, Rodado R, Rothenbuhler A, Saraff V, Shoemaker AH, Shore EM, Silve C, Turan S, Woods P, Zillikens MC, Perez de Nanclares G, Linglart A. Diagnosis and management of pseudohypoparathyroidism and related disorders: first international Consensus Statement. Nat Rev Endocrinol 2018;14:476-500. 